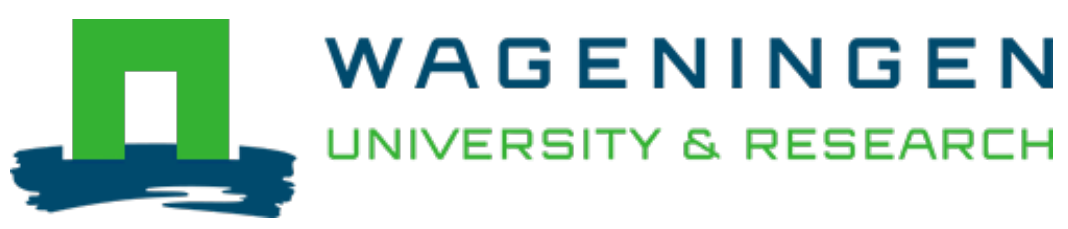

\title{
From natural flow to 'working river' : hydropower development, modernity and socio-territorial transformations in Lima's Rímac watershed
}

\author{
Journal of Historical Geography \\ Hommes, Lena; Boelens, Rutgerd \\ https://doi.org/10.1016/j.jhg.2018.04.001
}

This publication is made publicly available in the institutional repository of Wageningen University and Research, under the terms of article $25 \mathrm{fa}$ of the Dutch Copyright Act, also known as the Amendment Taverne. This has been done with explicit consent by the author.

Article 25 fa states that the author of a short scientific work funded either wholly or partially by Dutch public funds is entitled to make that work publicly available for no consideration following a reasonable period of time after the work was first published, provided that clear reference is made to the source of the first publication of the work.

This publication is distributed under The Association of Universities in the Netherlands (VSNU) 'Article $25 \mathrm{fa}$ implementation' project. In this project research outputs of researchers employed by Dutch Universities that comply with the legal requirements of Article $25 \mathrm{fa}$ of the Dutch Copyright Act are distributed online and free of cost or other barriers in institutional repositories. Research outputs are distributed six months after their first online publication in the original published version and with proper attribution to the source of the original publication.

You are permitted to download and use the publication for personal purposes. All rights remain with the author(s) and / or copyright owner(s) of this work. Any use of the publication or parts of it other than authorised under article $25 \mathrm{fa}$ of the Dutch Copyright act is prohibited. Wageningen University \& Research and the author(s) of this publication shall not be held responsible or liable for any damages resulting from your (re)use of this publication.

For questions regarding the public availability of this publication please contact openscience.library@wur.nl 


\title{
From natural flow to 'working river': hydropower development, modernity and socio-territorial transformations in Lima's Rímac watershed
}

\author{
Lena Hommes ${ }^{a, ~ *}$, Rutgerd Boelens a, b, c \\ ${ }^{a}$ Water Resource Management Group, Department of Environmental Sciences, Wageningen University, P.O. Box 47, 6700, AA, Wageningen, The Netherlands \\ ${ }^{\mathrm{b}}$ CEDLA (Centre for Latin American Research and Documentation), University of Amsterdam, Roetersstraat 33, 1018, WB, Amsterdam, The Netherlands \\ ${ }^{\mathrm{c}}$ Department of Geography, Planning and International Development, University of Amsterdam, P.O. Box 15629, 1001, NC, Amsterdam, The Netherlands
}

\section{A R T I C L E I N F O}

\section{Article history:}

Received 28 October 2016

Received in revised form

18 March 2018

Accepted 4 April 2018

\section{Keywords:}

Hydropower

Modernity

Hydrosocial territories

Environmental history

Urbanization

Lima

\begin{abstract}
A B S T R A C T
By combining scholarship on modernity, urbanization and territory, this paper analyses how urbanbased visions and ambitions have been realized in hydropower development and specific water access and control arrangements in the Rímac watershed in Lima, Peru. The discourses that sustained and promoted hydropower plant construction and associated development projects in the watershed are scrutinized, showing how the dream of conquering nature through engineers' technical skills was enmeshed with political agendas and visions of modernizing not only nature, but also people. Besides the historical analysis, the paper also explores how historical physical-ecological, legal, social and symbolic reconfigurations continue to shape hydrosocial relations between the city of Lima and the Rímac watershed. Analysing the current management of the watershed's highland lakes and community water use from the hydropower company's tunnels shows how the history of the Rímac is not a clear cut story of water deprivation but rather of complex, entangled, multidimensional relations and dependence. In the context of increasing pressure on water resources, the socio-territorial arrangements and the watershed's history itself are becoming matters of discussion.
\end{abstract}

๑) 2018 Elsevier Ltd. All rights reserved.
Aspirations of modernity have long steered the transformation of landscapes, technological development, industrialization and people's desire to become masters of the environment and their own destiny. ${ }^{1}$ Importantly, modernity has often been a profoundly political-geographical project that set out to transform nature and people in the name of progress, development and - in general terms - betterment. ${ }^{2}$ Two key materializations of modern ideas have deeply shaped the history of Lima, Peru's capital, and its

\footnotetext{
* Corresponding author.

E-mail addresses: lenaho@gmx.net (L. Hommes), Rutgerd.boelens@wur.n (R. Boelens).

1 Z. Bauman, Liquid Times: Living in an Age of Uncertainty, Cambridge, 2007; L. Mumford, The Myth of the Machine II: The Pentagon of Power, New York, 1971; M Weber, General Economic History, New Brunswick, 1981 (originally published in 1927).

2 M. Kaika, Cities of Flows: Modernity, Nature and the City, London, 2005; N. Smith Uneven Development: Nature, Capital, and the Production of Space, Oxford, 1984; E. Swyngedouw, Modernity and hybridity: nature, regeneracionismo, and the production of the Spanish waterscape, 1890-1930, Annals of the Association of American Geographers 89 (1999) 443-465.
}

adjacent watersheds since the nineteenth century: accelerated urban development - the playing field for realizing modern living - and electricity - an integral part of this modern way of life and progress. Aspirations of modernity, urbanization and electrification led to the successive construction of small hydropower plants and associated hydraulic infrastructure in the Rímac watershed, reconfiguring hydrosocial rural-urban relations in profound ways.

By combining scholarship on modernity, hydrosocial territories and rural-urban relations, this paper analyses how urban-based modern values, visions and ambitions have been materialized in hydraulic technologies and water access and control arrangements that shape hydrosocial relations in the watershed up to today. We show that the conquest of disobedient and savage water flows by engineers' visions and technical skills was central and deeply enmeshed with political agendas and ideas of civilizing and modernizing nature and people. In particular, discourses that sustained and promoted hydropower plant construction and associated development projects in the Rímac watershed are analysed to show how engineers and companies have inscribed their ideas of progress and modernity in hydraulic and territorial designs. The 


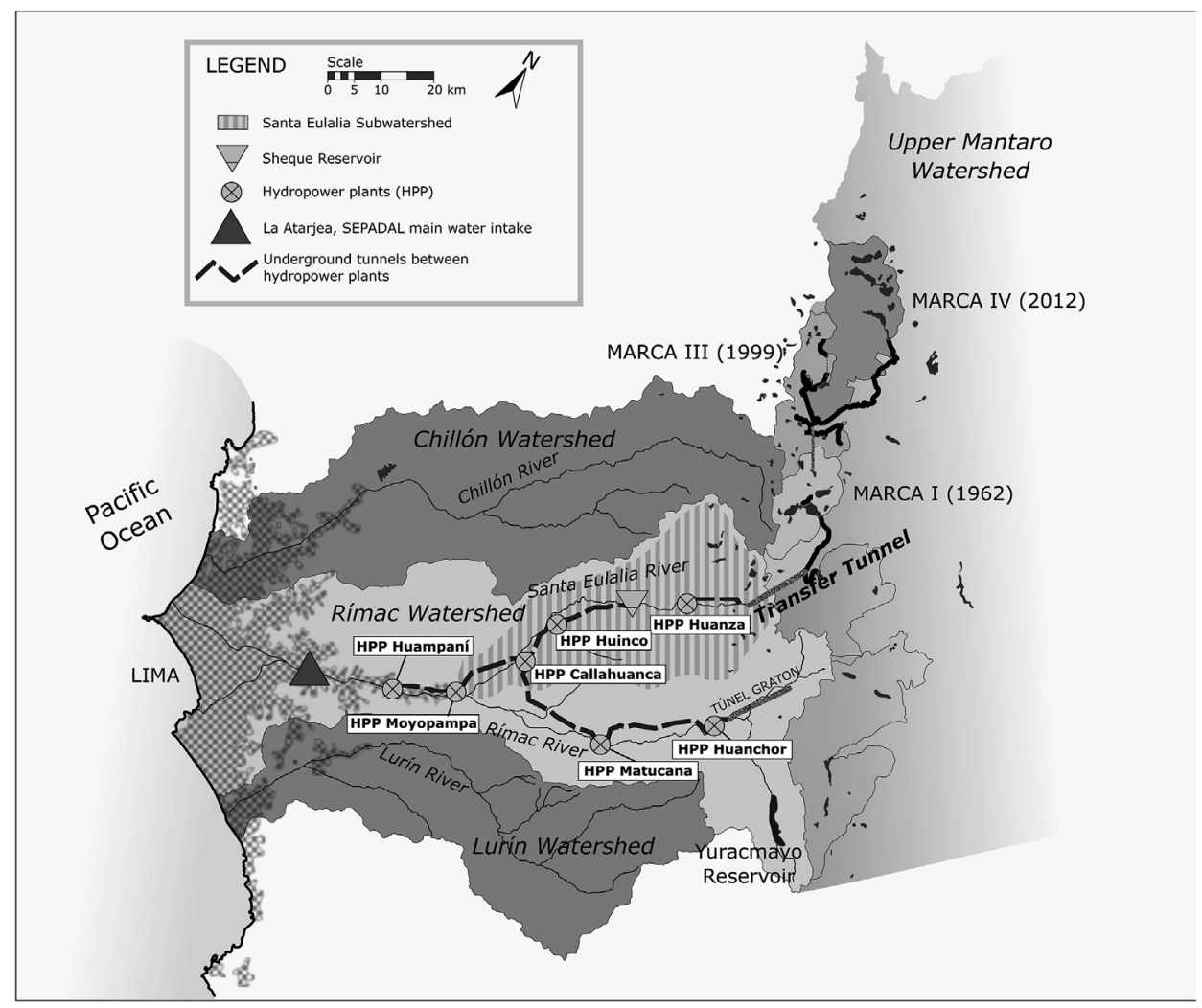

Fig. 1. Lima's watersheds and hydraulic infrastructure.

analysis scrutinizes how historical physical-ecological, legal, social and symbolic reconfigurations continue to shape hydrosocial relations between the growing city of Lima and the Rímac watershed. In the face of urban growth and climate change, the Rímac watershed's history is increasingly becoming a subject of interest again due to intensifying competition for water resources. Regional history has become a matter of negotiation and subject to political debate, as the diverse actors currently present in the watershed remember it differently and according to their own particular interests and positions. This demonstrates how the hydrosocial territories, in which rural and urban actors in the Lima region are entangled, continue to be renegotiated.

\section{The Rímac watershed}

The Rímac watershed is formed by the confluence of the San Mateo and the Santa Eulalia rivers and has a total extent of $3503 \mathrm{~km}^{2}$ with a river course length of $127 \mathrm{~km}$ (Fig. 1). ${ }^{3}$ The watershed's geography is highly varied. The upper watershed has steep mountain slopes, 145 lakes and wetlands. It is characterized by heavy rainfalls especially from December to March, with an average annual precipitation of $647 \mathrm{~mm} .{ }^{4}$ The lower part is a coastal desert area with an average yearly precipitation of $9 \mathrm{~mm}$. The heavy rains in the upper and middle watershed are the main water source feeding the Rímac river and lake system. The annual average flow rate in the lower watershed, before the intake of Lima's drinking

\footnotetext{
${ }^{3}$ Autoridad Nacional del Agua, Evaluación de los Recursos Hídricos en la Cuenca del Río Rímac, Lima, 2010.

4 Servicio Nacional de Meteorología e Hidrología del Perú [SENAMHI], Indicadores de Alteración Hidrológica del Río Rímac, Lima, 2014
}

water company, is currently $28 \mathrm{~m}^{3} / \mathrm{s}$, but with significant flow variations between wet and dry months. ${ }^{5}$ It is important to note that the river and highland lake system has been heavily modified by human intervention. Hydropower development led to the damming of highland lakes and water transfers from the Atlantic Mantaro watershed that substantially modified river flows. ${ }^{6}$

Politically, the watershed belongs to the department of Lima and the provinces of Lima and Huarochirí. Water users are diverse. In the upper and middle watershed there are numerous small peasant communities whose livelihoods are mainly based on agriculture and livestock breeding. Natural pasture areas are rainfed, whereas agricultural areas (an estimated 11,272 ha) are irrigated from highland lakes, mountain streams and direct water intakes from the Rímac and Santa Eulalia rivers. ${ }^{7}$ There are also mining operations in the upper watershed that account for approximately four per cent of water consumption in the watershed, and that pose a constant threat to water quality due to toxic mining tailings and

\footnotetext{
5 Autoridad Nacional del Agua, Evaluación de los Recursos Hídricos en la Cuenca del Río Rímac; SENAMHI, Indicadores de Alteración Hidrológica del Río Rímac.

${ }^{6}$ L. Hommes and R. Boelens, Urbanizing rural waters: rural-urban water transfers and the reconfiguration of hydrosocial territories in Lima, Political Geography 57 (2017) 71-80; F. Vega, W. Lavado and O. Felipe, Alteraciones hidrológicas debido a actividades antrópicas en la cuenca del río Rímac, Perú (1920-2013), unpublished document, Lima, 2015.

7 SEDAPAL, Plan Maestro de los Sistemas de Agua Potable y Alcantarillado, Lima 2014. Throughout this paper we refer to the Rímac and Santa Eulalia watersheds, the latter being a subwatershed of the former (see Fig. 1). We make the distinction between Rímac and Santa Eulalia only where relevant. When we talk about the Rímac watershed without particularly distinguishing Santa Eulalia, we refer to the watershed as a whole.
} 
waste discharges. $^{8}$

As of 2017, there are seven hydropower plants (HPPs) in the Rímac watershed with two more planned. Together they have a production capacity of $662 \mathrm{MW}$. Five of the seven HPPs were constructed between 1938 and 1965, and are currently owned by Italian multinational Enel. The two newer HPPs were constructed by mining companies to produce electricity for their operations throughout Peru. They return water flows to the riverbed after a few kilometres, whereas Enel's HPPs are connected by underground tunnels conducting water from one HPP to the next.

The Rímac watershed figures prominently in the debate about water supply for the megacity of Lima, as the majority of the city's ten million inhabitants receive their drinking water from this watershed and the trans Andean water transfers from the Mantaro watershed. ${ }^{9}$ As this paper shows, the intense and diverse usage of the Rímac watershed is the outcome of historical socio-territorial imaginaries, engineering projects and negotiations over water access and decision making.

\section{Research methods}

This paper is based on research conducted in 2015 and 2016, including interviews with over forty stakeholders in Lima and rural communities in the Rímac watershed. In six peasant communities (four in the upper and middle Santa Eulalia subwatershed, and two in the upper Rímac watershed), farmers, community leaders and local government representatives were interviewed. Interviews were semi-structured, inquiring about current local water management practices and relations to the hydropower companies, as well as the history of hydropower development in the area. Moreover, participation in relevant events such as communal work actions and meetings formed part of the research.

In Lima, interviews with former and current employees of the two main electricity companies, Lima's drinking water company SEDAPAL and governmental institutions (Ministry of Energy and Mining, national and local water authorities) were conducted. Questions and subsequent analysis focused on the history of hydropower development, current dynamics and communities' territorial and political positions. Archival research was conducted in the National Library, the National Archive and the archive of Lima's Museum of Electricity. In the National Library, manuscripts and speeches of historically influential engineers (Santiago Antunez de Mayolo, Pablo Boner and others) were reviewed, analysing ideas, discourses and visions that motivated and sustained hydraulic development in the region. The National Archive holds official records of ministries on hydropower development disputes. The Museum of Electricity has annual reports (1901-1969) and promotional material of electricity companies. Articles in the journal Electroténica and national newspaper El Comercio about hydraulic development in Lima's basins were reviewed for the years immediately before and after the inauguration of the main hydraulic works.

\section{Modernity, hydraulic technology and rural-urban territories}

To understand the ways in which the Rímac watershed and its relation to Lima have been reconfigured since the arrival of the hydropower companies, we use a framework that combines

\footnotetext{
8 Autoridad Nacional del Agua, Evaluación de los Recursos Hídricos en la Cuenca del Río Rímac, 179; Labor Pasco, Informe Conflicto Tamboraque, Cerro de Pasco, 2010.

${ }^{9}$ For an analysis of these water transfers, see Hommes and Boelens, Urbanizing rural waters.
}

scholarship on modernity, urbanization and territory. We analyse how specific ideas of modernity - partly related to urbanization and coupled with business interests - were materialized in hydraulic technologies and how these, in turn, affected the physicalecological, economic, legal and socio-cultural dynamics in the Rímac watershed. We thereby show how discussions about modernity and hydrosocial territories can complement each other, and how they can be applied to understand hydropower and urban development's multiscalar and multidimensional transformation dynamics.

The West's iconic referent for modernity is Prometheus, the mythical hero who stole fire from Mount Olympus to bring light and hope to humanity, who would then be empowered to shape progress and development themselves. Ever since, social, technological and ecological utopias have envisioned liberation from the dark ages and dependence on the whims of gods and nature. Francis Bacon's New Atlantis forecasts people's radical split from traditional subsistence economies thanks to natural science, nature's utter domestication and technological development that would guarantee societal perfection. ${ }^{10}$ In a similar manner, James Scott characterizes more recent 'high modernism' as a local-global project built on 'supreme self-confidence about continued linear progress, the development of scientific and technical knowledge, the expansion of production, the rational design of social order, the growing satisfaction of human needs, and, not least, an increasing control over nature'. ${ }^{11}$ Other characteristic features of modernity are instrumental rationalities and the deep belief in the calculability of societal choices and preferences, as well as the intent to make cultural meanings, values, language and knowledges commensurate in order to arrive at one common metric. ${ }^{12}$ In consequence, reflecting foundational modernist notions as expressed by liberal-utilitarian thinker Jeremy Bentham, ideas and projects are often promoted as modern in the name of the common good and maximizing utility. ${ }^{13}$

Even though modernity is not an unambiguous concept, as it is shaped by the particular ideas and identities of those that push modernization at specific moments, the belief in the ability and necessity to plan the socio-natural future is always central. ${ }^{14}$ This belief, emphasizing agency and humanity's ability to actively shape the physical environment and society as wished, is intrinsically based on an epistemological and ontological divide between society and nature. ${ }^{15}$ Nature is viewed as the other, non-human, disordered and savage, an entity that needs to be colonized, civilized and subjected to humanity's will. $^{16}$

One particularly important modernizing project that requires nature to be transformed and put at the service of humanity is urban development. Created by industrial society and distant from what is considered rural, traditional and backward, cities have been

\footnotetext{
10 F. Bacon, The New Atlantis, Montana, 1997 (originally published in 1626).

11 J.C. Scott, Seeing Like a State: How Certain Schemes to Improve the Human Condition Have Failed, New Haven, 1998, 89.

12 Bauman, Liquid Times; D. Haraway, Simians, Cyborgs, and Women: The Reinvention of Nature, New York, 1991; T. Lemaire, De Val van Prometheus: Over de Keerzijden van de Vooruitgang, Baarn, 2010.

13 J. Bentham, The Principles of Morals and Legislation, Amherst NY, 1988 (originally published in 1781); J. Bentham, Panopticon or the inspection-house, in: M. Bozovic (Ed.), The Panopticon Writings, London, 1995 (originally published in 1787-1791), 29-95.

14 S.N. Eisenstadt, Multiple modernities, Daedalus 129 (2000) 1-29.

15 B. Latour, We Have Never Been Modern, Cambridge, 1993.

16 Z. Bauman, Modernity and Ambivalence, Cambridge, 1991; M. Foucault, Discipline and Punish: The Birth of the Prison, Harmondsworth, 1977; S. Oliver, The Thames embankment and the disciplining of nature in modernity, The Geographical Journal 166 (2000) 227-238.
} 
portrayed as exclusive arenas of modernity. ${ }^{17}$ The transformation of nature is both necessity and an aspiration to turn cities into civilized, modern spaces with sufficient and convenient supplies of water, food and energy. ${ }^{18}$ In this quest for resources a city's reach extends far beyond the traditionally considered city boundaries, changing rural-urban relations through the transformation of space and the rules governing it. ${ }^{19}$ As we will show, in the case of Lima it was first electricity and later the provision of drinking water that was regarded as crucial for urban modernity. The resulting hydraulic projects changed not only river flows but were intrinsically connected to dreams of modernizing the rural watershed and its inhabitants.

In this paper we demonstrate the usefulness, and, in fact, necessity, of understanding urban modernization as a profoundly territorial project. It is territorial because it involves processes in which cities newly delineate their areas of influence, creating hierarchical, space-based relationships with rural areas, regulating actions and the use of space and, in particular, resources such as land and water. ${ }^{20}$ In a general sense, Erik Swyngedouw and Rutgerd Boelens argue that 'territory is the socio-materially constituted and geographically delineated organization and expression of and for the exercise of political power'. ${ }^{21}$ In a similar manner, we do not consider territories as necessarily associated with nation state boundaries, but rather as more broadly defined bounded political spaces: bounded in the sense of geographically demarcated and political in terms of socio-spatial authority and hierarchical power relations. ${ }^{22}$ Therefore, a territory is not a socially disempowering technical device as often implied in traditional geography. ${ }^{23}$ Instead, it is 'the socio-spatial context where the "living together" is produced, organized and negotiated'. ${ }^{24}$ This means that territories are composed of social, symbolic and physical constituents: relations and actions, legal and political arrangements, discourses, physical artefacts and ecological systems. ${ }^{25}$ These constituents blend together and mutually (re)produce each other at a given time and space. For example, social relations, discourses and practices produce material changes in nature and ecological relations at specific moments, and are in turn shaped by these ecologies.

Territories, therefore, are dynamic and historically constituted. ${ }^{26}$ They evolve out of social encounters and are the effect of

\footnotetext{
17 B. Echeverría, Un concepto de modernidad, Contrahistorias 11 (2008) 7-18; N. Heynen and E. Swyngedouw, Urban political ecology, justice and the politics of scale, Antipode 34 (2003) 898-918.

18 J.M. Banister and S.G. Widdifield, The debut of 'modern' water in early twentieth century Mexico City: the Xochimilco potable waterworks, Journal of Historical Geography 46 (2014) 36-62; Mumford, The Myth of the Machine II.

19 W. Cronon, Nature's Metropolis: Chicago and the Great West, New York, 1991; N. Heynen, M. Kaika and E. Swyngedouw (Eds), In the Nature of Cities, London, 2006; M. Kaika, Dams as symbols of modernization: the urbanization of nature between geographical imagination and materiality, Annals of the Association of American Geographers 96 (2006) 276-301.

20 B. Baletti, Ordenamento territorial: neo-developmentalism and the struggle for territory in the lower Brazilian Amazon, The Journal of Peasant Studies 39 (2012) $573-598$.

21 E. Swyngedouw and R. Boelens, And not a single injustice remains: hydro-territorial colonization and techno-political transformations in Spain, in: R. Boelens, T. Perreault and J. Vos (Eds), Water Justice, Cambridge, 2018, 117.

22 M. Antonsich, Rethinking territory, Progress in Human Geography 35 (2010) 422-425; Swyngedouw and Boelens, And not a single injustice remains.

23 See, for example, S. Elden, Land, terrain, territory, Progress in Human Geography 34 (2010) 799-817; P. Robbins, Political Ecology: A Critical Introduction, Oxford, 2004.

24 Antonsich, Rethinking territory, 425.

25 R. Boelens, J. Hoogesteger, E. Swyngedouw, J. Vos and P. Wester, Hydrosocial territories: a political ecology perspective, Water International 41 (2016) 1-14.

${ }^{26}$ A.M. Brighenti, On territorology: towards a general science of territory, Theory, Culture and Society 27 (2010) 52-72.
}

social relations' material inscriptions, which define what spaces look like and how social relations are organized. ${ }^{27}$ The making of territory is an interactive and continuous process that emerges from imaginaries of what a territory and its judicial, political, economic, social, cultural, affective and physical aspects should look like. Values and aspirations - such as those connected to modernity - are projected onto a space and its people and institutions. Practices become directed at realizing the envisaged socio-territorial project. Boundaries are redrawn. Yet, because of the contested nature of project (ion)s, values and aspirations, territories are not stable or permanent, but need to be understood as continuously negotiated. ${ }^{28}$ To realize or maintain socio-territorial projects, different actors mobilize the resources available to them. ${ }^{29}$ The resulting struggles can be open or subtle, finding expression in, for example, hidden everyday struggles, disputes about discourses or recognition of knowledge, or 'mimicry strategies' which feign acceptance of dominant arrangements to protect local territorial governance. $^{30}$

Efforts to modernize always change nature, space and social organization, but they are not always a territorial undertaking with ordering practices that delineate space under a specific authority. In the case of efforts related to urbanization, however, modern projects for urban water and energy supply redraw city boundaries and entwine urban and rural spaces, communities and waters. Rural-urban social, symbolic and physical relations become redefined; urban modernity operates as a territorial project.

In the modernist transformation of natural resources and rural territories, knowledge and technical capacity to conquer nature are central, and engineers take on a specific role. ${ }^{31}$ Beyond merely technical agents, they are often key promoters of modern projects who inscribe their ideas of progress, development and modernity in hydraulic designs and political-geographical interventions. ${ }^{32}$ Some designers and engineers may not consciously envisage the sociopolitical and cultural effects of hydraulic technology beforehand, whereas other design choices deliberately aim to change a region's

\footnotetext{
27 J. Agnew, The territorial trap: the geographical assumptions of international relations theory, Review of International Political Economy 1 (1994) 53-80; Baletti, Ordenamento territorial.

$28 \mathrm{~N}$. Brenner, Between fixity and motion: accumulation, territorial organization and the historical geography of spatial scales, Environment and Planning D: Society and Space 16 (1998) 459-481; J. Hoogesteger, R. Boelens and M. Baud, Territorial pluralism: water users' multi-scalar struggles against state ordering in Ecuador's highlands, Water International 41 (2016) 91-106.

29 A. Bebbington, D.H. Bebbington and J. Bury, Federating and defending: water, territory and extraction in the Andes, in: R. Boelens, D.H. Getches and J.A. GuevaraGil (Eds), Out of the Mainstream: Water Rights, Politics and Identity, London, 2010, 307-328; A. Escobar, Territories of Difference: Place, Movements, Life, Redes, Durham NC, 2008.

${ }^{30}$ R. Boelens, Water, Power and Identity: The Cultural Politics of Water in the Andes, London, 2015; J.C. Scott, The Art of Not Being Governed: An Anarchist History of Upland Southeast Asia, New Haven, 2009.

31 See, for example, W.E. Bijker, Dikes and dams, thick with politics, Isis 98 (2007) 109-123; F. Molle, P.P. Mollinga and P. Wester, Hydraulic bureaucracies and the hydraulic mission: flows of water, flows of power, Water Alternatives 2 (2009) 328-349; Oliver, The Thames embankment.

${ }^{32}$ C. Sanchis-Ibor, R. Boelens and M. García-Mollá, Collective irrigation reloaded: re-collection and re-moralization of water management after privatization in Spain, Geoforum 87 (2017) 38-47; J.B. Teisch, Engineering Nature: Water, Development and the Global Spread of American Environmental Expertise, Chapel Hill NC, 2011, 9; M. Callon, Techno-economic networks and irreversibility, in: J. Law (Ed.), A Sociology of Monsters: Essays on Power, Technology and Domination, London, 1991, 132-165; M. Callon, J. Law and A. Rip (Eds), Mapping the Dynamics of Science and Technology: Sociology of Science in a Real World, London, 1986.
} 
socio-political and cultural makeup by altering water flows. ${ }^{33}$ Jessica Teisch, citing the North American engineer Frederick Newell, states that "many engineers ... viewed themselves as "missionaries of light and progress", pioneers of a "better and higher degree of civilization"'. ${ }^{34}$ Modernized, technologically reconfigured landscapes may thus be considered as 'humanised nature' that contains history, cultural meanings and power relations. ${ }^{35}$ Accordingly, hydraulic technology is inherently social and material, and reconfigures territories in their whole hydrosocial complexity. Given the importance of the role engineers assume in modern hydraulic projects, part of this paper's analysis focuses on such engineers, their discourses and aspirations, showing how they have been central agents in reconfiguring rural-urban hydrosocial territories.

In the case of Lima's urban development and its relation to the surrounding watersheds, state institutions have so far focused on studying the hydrology of the watersheds. There is little research on historical reconfigurations triggered by ideologies and demands for water and energy. ${ }^{36}$ This is surprising considering the importance of Lima and the urgency of understanding and addressing the capital's water issues. Likewise, at national level, critical literature on river basin engineering in Peru is limited. As an exception, Barbara Lynch shows how water scarcity discourses in Peru are produced and how they facilitate water transfers from highland areas to agroexport production on the desert coast, resulting in water use conflicts. ${ }^{37}$ Our particular aim, however, is an in-depth analysis of the role modern ideologies played in the justification, design and execution of hydraulic projects that substantially changed rural-urban relations and water flows in Lima. The contribution of this paper is thus conceptual as well as empirical.

\section{Transforming the 'river that talks' into 'the river that works'}

The history of the impact of urban development on the Rímac watershed can be divided into three phases: the first (1890-1925) being the initial interventions of downstream water users in upstream areas; the second (1925-1970) marked by the intensified construction of hydropower plants in the watershed driven by development visions; the third (1970 to today) shaped by Lima's growing need for drinking water resources. The emphasis of our historical analysis is on the second period, where urban demands for energy and modernity transformed the Rímac from the 'river that talks' (the original Quechua meaning of the name) into 'the hardest working river in the world', radically changing hydrosocial relations. ${ }^{38}$ Understanding the historical geography of these dynamics helps to uncover the enduring impact they have on present day rural-urban relations, as will be discussed in the second part of the paper.

\footnotetext{
33 M. Carey, A. French and E. O'Briend, Unintended effects of technology on climate change adaptation: an historical analysis of water conflicts below Andean glaciers, Journal of Historical Geography 38 (2012) 181-191; L. Hommes, R. Boelens and $\mathrm{H}$. Maat, Contested hydrosocial territories and disputed water governance: struggles and competing claims over the Ilisu Dam development in Southeastern Turkey, Geoforum 71 (2016) 9-20.

34 F.H. Newell quoted in Teisch, Engineering Nature, 9.

35 B. Pfaffenberger, Fetishised objects and humanised nature: towards an anthropology of technology, Man 23 (1988) 244.

36 With exception of Hommes and Boelens, Urbanizing rural waters

37 B. Lynch, River of contention: scarcity discourse and water competition in highland Peru, Georgia Journal of International and Comparative Law 42 (2013) 69-92. See also G. Damonte, Redefiniendo territorios hidrosociales: control hídrico en el valle de Ica, Perú (1993-2013), Cuadernos de Desarrollo Rural 12 (2015) 109-133; J. Hoogesteger and A. Verzijl, Grassroots scalar politics: insights from peasant water struggles in the Ecuadorian and Peruvian Andes, Geoforum 62 (2015) $13-23$.

38 H. Buse, Huinco 240,000 KW, Lima, 1965, 3.
}

\section{Institutionalization of control over highland lakes, 1890-1925}

As agricultural production of cotton, sugarcane and avocado on plantations in the middle and downstream valleys of the Rímac watershed intensified in the course of the late nineteenth century, so did the interests in upstream water resources. These resources were imagined to be bountiful and freely available for downstream agricultural development, which, in 1904, led downstream landowners to start exploring upstream water resources through a state led study of highland lakes' storage capacity. ${ }^{39}$ This study resulted in the state financed construction of several dams in the highland lakes to seize rainwater for downstream agriculture. The fact that both the study and the dam projects were financed by the state, shows the strong association of state institutions with downstream water requests.

Though community responses are scarcely documented, archival documentation reveals that in 1921 the community of San Lorenzo de Huachupampa complained to the Ministry of Development and opposed plans to construct a reservoir, arguing that it would deprive them of their agricultural livelihoods: 'it is these territories, irrigated with our very own labour, that are now destined to be expropriated for the benefit of the powerful landowners of the Rímac Valley ... no monetary compensation will help us as we will be left with nothing to work on ... leaving us with no choice but to abandon our village altogether'. In response, a state engineer claimed a different reality, trying to convince the minister that 'one has to acknowledge the truth of the facts ... that they have to leave the village seems exaggerated, only a very small part of their territory will be flooded'. ${ }^{40}$ Despite the fact that the project in question was never realized, Huachupampa's complaint shows how the watershed was not simply an empty, unused space for hydraulic dreaming and planning. ${ }^{41}$ Rather, territorial control has been and remains contentious.

A few years after the first highland lakes were dammed, the presence of the Empresas Electricas Asociadas (Associated Electric Companies, hereafter referred to as the Electric Companies) in the watershed became more evident every year. Founded in 1904 as a merger of smaller electricity companies, the Electric Companies became a central player. From the beginning they had important political and financial connections nationally and abroad, for example through the first general manager Mariano Prado Ugarteche, member of the powerful Prado dynasty and son and brother of presidents Mariano Prado and Manuel Prado y Ugarteche. ${ }^{42}$

In 1914 the company signed a contract with the municipality of Lima to provide the city's public lighting, which subsequently created the need to secure further water resources for increasing hydropower production. ${ }^{43}$ The company thus joined forces with the owners of Rímac valley estates, state officials and downstream industries and, in 1920, founded the Huarochirí Lagoons Oversight

\footnotetext{
39 Letter from the president of the central union of the Rímac Valley to the director of public works and irrigation, 10 June 1904, Collection Aguas de Regadío [hereafter CAR], National Archive of the Republic, Lima [hereinafter NAR], Document 10.

40 Letter from J. Valdez to the Ministry of Development about the suspension of construction works in Autisha Pucchi, 27 June 1921, CAR, NAR, Document 83.

41 See also the complaints by the communities of Huanza, Carampoma and San Pedro de Casta about flooding and other damage caused by the oversight board and electric companies works in Letters to the Ministry of Development, 13 April and 26 June 1928, CAR, NAR.

42 L. Repetto and N. Hidalgo, Y Se Hizo Luz, 127 Años de Generación Eléctrica en Lima, unpublished document, Lima, 2012.

43 At this time the company was in possession of two hydropower plants and one thermal power plant (HPP Chosica, 1903; HPP Yanacoto, 1907; Thermal PP Santa Rosa, 1895)
} 
Board (Junta de Vigilancia de Las Lagunas de Huarochirí) to dam and administer highland lakes. ${ }^{44}$ Upstream rural communities were not on the board, though the highland lakes were in their community constituencies. Only downstream water users with political and economic power were members.

In the following years, several more highland lakes were dammed with financing from the Electric Companies and backed by official state authorization. ${ }^{45}$ The step-by-step acquisition of control over upstream water resources makes clear how slowly but continuously water flows, water control arrangements and the position of different water user groups changed. Even though, in most cases, communities were still able to use water from the newly built reservoirs, the authority and terms of this water use changed and became dependent on the approval of downstream actors. Political relations, state support for valley land owners and the hydropower company and exclusion of rural communities became institutionalized in the oversight board, which then drove the materialization of these relations in retaining walls, gates and reservoirs, that in turn profoundly reconfigured the hydrosocial territories of the Rímac watershed. In other words, through the interplay among socio-cultural, legal-institutional, economic and physical arrangements, new space-defining patterns, water flows and relations were established that set the conditions for future hydropower plant construction.

\section{Hydropower development and water transfers: dreams of} civilization and the domination of nature, 1925-1970

Territorial changes in the Rímac watershed accelerated when engineer Pablo Boner arrived in 1925. Born in 1889 in Switzerland but widely travelled, he is said to have fallen in love with the Andean mountains and their possibilities for hydropower development. ${ }^{46}$ Taking long hikes to the Huarochirí Lakes to determine their capacities, he became known as the 'water hunter' (el buscador del agua), and is still famous by that name in Andean communities today (Fig. 2 and Fig. 3). ${ }^{47}$ His expeditions resulted in an ambitious plan for further damming of the Huarochirí Lakes, constructing six hydropower plants and an inter-basin water transfer from the Rímac to the Santa Eulalia subwatershed. Approved in 1933, the plan was later complemented by a trans Andean water transfer (known as Marca I) that diverts water from the Amazonian Mantaro to the Santa Eulalia watershed.

As a result of Boner's projects hydropower plants came to characterize the landscape and control the watershed's water resources, conducting water from one plant to the next through underground tunnels (Fig. 1), leaving little in the natural riverbed especially in the dry season. From then onwards river flows were no longer nature's doing but came to be regulated by engineering decisions and business considerations made in Lima. The city's spatial reach - in its material-geographical as well as socio-political sense - extended, incorporating the rural areas of the Rímac watershed into Lima's hydrosocial territory. This, however, does not imply that rural communities were left without water. In some cases communities benefited from trans Andean water transfers through the so-called 'water vents' (ventanas) from the tunnels. Yolanda Ramirez has also documented how compensation

\footnotetext{
44 Letter from G. Bianchini to the president of the republic about the companies' financing of damming the lagoons of Huarochirí (1933), CAR, NAR, Report 1642.

45 Empresas Eléctricas Asociadas, Law authorizing works for damming the Lakes of Huarochirí, Memoria Anual, Museum of Electricity Archive, Lima [hereafter MEA], 1934, 96.

${ }^{46}$ Neue Zürcher Zeitung, Pablo Boner: ein Schweizer Pionier, Morgenausgabe, 13 November 1964, 21.

47 Buse, Huinco, 47
}

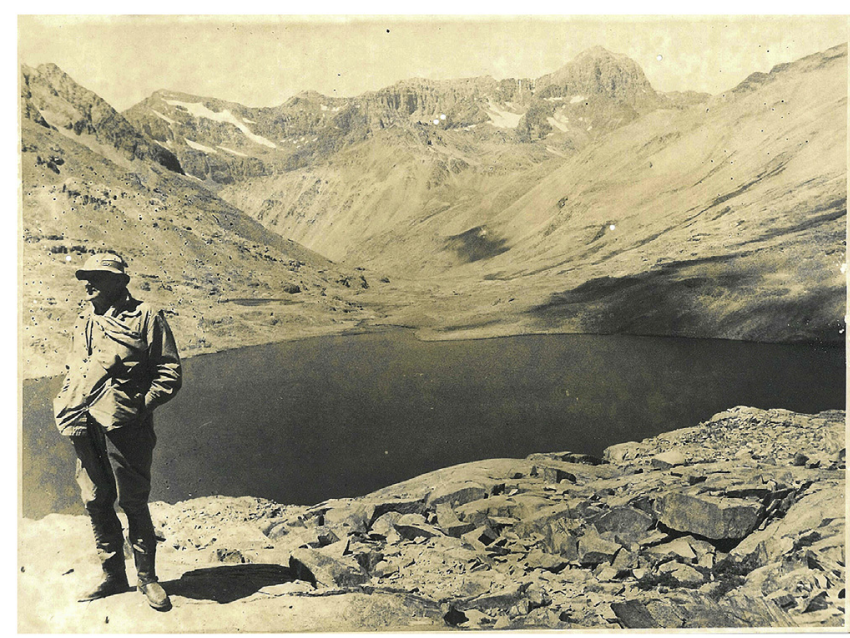

Fig. 2. Pablo Boner, the water hunter, during an expedition to the Huarochirí Lakes. Source: Private Archive Andrés Boner, Lima, Peru.

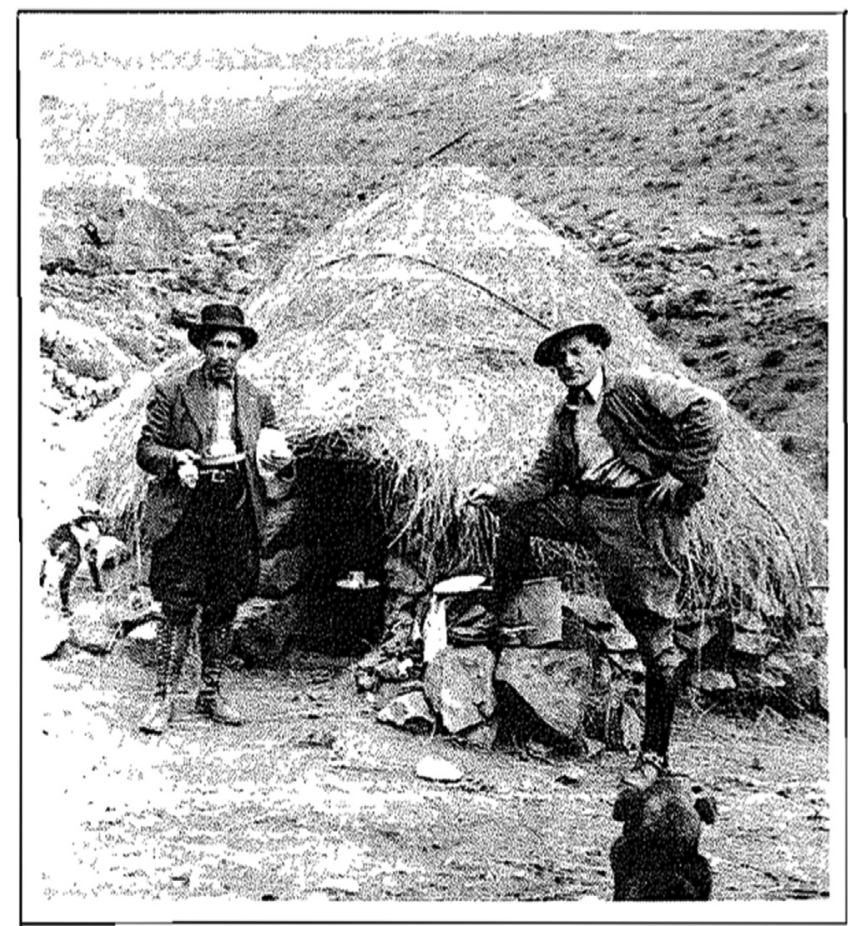

Fig. 3. 'Pablo Boner in the Huarochirí mountain range at $4600 \mathrm{~m}$ above sea level' Source: Cámara de Comercio Suiza en el Perú, Presencia Suiza en el Perú 1991, Lima, 1991, 256.

payments brought certain benefits to communities. ${ }^{48}$

Besides legal and state support, hydropower development was profoundly sustained by modernist discourses, values and socioterritorial imaginaries, particularly about civilization and the domination of nature. ${ }^{49}$ Hydropower development around Lima was promoted as a prerequisite for development and progress. As

\footnotetext{
48 Y. Ramirez Villacorta, La penetración capitalista en una comunidad campesina: el caso de San Pedro de Casta, Revistas PUCP (1980) 39-70.

49 Banister and Widdifield, The debut of 'modern' water; M. Gandy, Rethinking urban metabolism: water, space and the modern city, City 8 (2004) 363-379; Kaika, Dams as symbols of modernization.
} 
the Electric Companies remarked on their sixtieth anniversary: 'the progress of people is conditioned by several basic factors, among them the electric industry .... The great progress of Metropolitan Lima has had and will continue to have the Electric Companies as a loyal and efficient ally'. ${ }^{50}$ In a similar manner, a co-financier of the HPPs called electricity 'the lifeblood of any modern industrial city' and national engineering hero Santiago Antúnez de Mayolo declared that 'Lima, the Pearl of the Pacific, needs to shine at night with potent bundles of light that extend over her and neighbouring populations'. ${ }^{51}$

The best and possibly only way to electricity and progress was seen to be engineering genius and the domination of nature. Peru's geography was regarded as both a blessing and a curse: a blessing because of the great potential for hydropower that the Rímac watershed's topography offers; a curse because the water resources to fully realize that potential were mainly located in the Amazonian Mantaro basin. Natural conditions were accordingly seen as a 'natural injustice' that needed to be overcome in order for humanity to progress towards modernity. ${ }^{52}$ The powerful conviction that the Andean highlands' water flow regimes could be neatly planned, that water's diverse meanings, values, uses and rights could and should be calculated and designed, that water flows would follow the logic of capital flows, and that water governance necessarily must be guided by an instrumental rationality of maximizing utility, were key to the Rímac's modernization project:

Today the Santa Eulalia River has been conquered, until the last drop of its potential energy is squeezed .... Without Boner's dreams none of these industrial projects would be a reality, nor would Lima be the best illuminated city in South America. ${ }^{53}$

This transformation of nature had to be achieved through technical genius. Different portrayals of the massive hydraulic undertakings of Boner and the Electric Companies show how they were not simple outcomes of unemotional technical evaluation, but rather materializations of the modernist dream of engineering as a liberating and civilizing mission:

Technical design means liberating men from their struggle for existence and giving them a better opportunity to develop their personality and soul, to become a higher class of human being, more intelligent and technically better equipped to live peacefully in the future. ${ }^{54}$

Men's labour has dominated the landscape and regulated raging torrents. Works of civilization in its most exact sense: dominance and utilization, true conquest for the community's benefit .... Great victory for men, their science and determination! ${ }^{55}$

Technical hydraulic designs liberate through the domination of landscapes, water and ultimately also Andean highland villagers, who were portrayed as backward. The authority and ability to dominate were granted to engineers, and their hydraulic works

\footnotetext{
50 Empresas Eléctricas Asociadas on the occasion of its sixtieth birthday, Memoria Anual, MEA, 1934, 96.

51 Speech by W. Boveri during a ceremony at the National University of Engineering, Lima, 1960; S. Antúnez De Mayolo, Génesis de los servicios eléctricos de Lima 1929, National Library of Peru, Manuscripts and Rare Books Collection, Lima.

52 H. Buse, Huinco: primeras victorias - batalla por el agua: Primera parte, El Comercio, 10 June 1959, 3.

53 El Personaje de la Noticia: Boner, Creador de Energía, La Prensa, 10 November 1961

54 Speech by W. Boveri.

55 Buse, Huinco: primeras victorias, 3.

56 Director of the Electric Companies G. Bianchini during the inauguration of
} Huinco HPP, 1965.

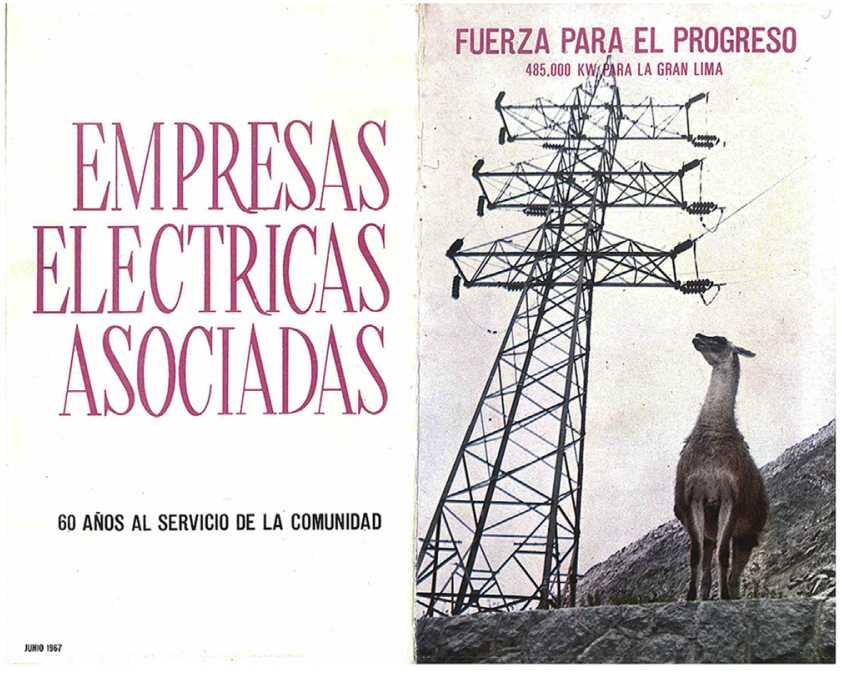

Fig. 4. Electric Companies Brochure: ' 60 years serving the community' and 'Power for progress - 485,000 KW for the Great Lima', 1967. Source: Private Archive Andrés Boner, Lima, Peru.

were described as 'awe inspiring altars devoted to the progress of the Peruvian nation'. ${ }^{56}$ Attributing symbolical preeminence to engineers and their works automatically renders any resistance to projects illegitimate interference with progress and the national good. A powerful imaginary thus directs people towards choosing progress over backwardness; affected communities are described as needing civilization, which justifies interventions. ${ }^{57}$ Hydropower development then becomes a civilizing mission turning savage and supposedly unused waters into workers for progress and saving rural people from the dark. The brochure for the Electric Companies' 1967 anniversary illustrates this vision, stating that 'the hydroelectric works have paved the way to progress for local communities'. ${ }^{58}$ The same brochure contrasts a power line, symbolizing progress, with a llama, symbolizing local livelihoods and backwardness (Fig. 4). This illustrates how the definition of what is modern is always relational. It is defined through contrasting the modern (electricity and urban development) with obsolete, traditional rural lifestyles. Besides this discursive and physical differentiation between urban and rural, the dams, hydropower plants, access roads and redirected water flows also create important irreversible links between the two. Urban and rural actors, imaginaries, practices and materialities become enmeshed in a shared, complex and ambiguous hydrosocial territory.

Besides installing light and building roads in communities, the Electric Companies also started a project with Swiss cooperation to support local development by introducing Swiss cattle breeds and cheese making to local communities, 'enabling the indigenous people to improve their material position, within the limitations of their education,. ${ }^{59}$ While some see this as an early form of corporate social responsibility, it can also be seen as a vision in which not

\footnotetext{
57 R. Boelens and N.C. Post Uiterweer, Hydraulic heroes: the ironies of utopian hydraulism and its politics of autonomy in the Guadalhorce Valley, Spain, Journal of Historical Geography 41 (2013) 44-58.

58 Associated Electric Companies, Empresas Electricas Asociadas: 60 años al servicio de la comunidad, 1967, Private Archive Andrés Boner, Lima.

59 Letter from the Swiss Embassy in Peru to the technical cooperation delegate, 22 August 1961, Swiss Federal Archives, Bern, t.941.1, 1. See also A. Sanders, 'Wonderland Peru': migration and the making of an Andean Switzerland, in: P. Purtschert and H. Fischer-Tiné (Eds), Colonial Switzerland: Rethinking Colonialism from the Margins, London, 2015, 110-132.
} 
only nature but also people needed to be civilized and brought closer to the modernity of urban and foreign elites. ${ }^{60}$ Beyond that, a letter from the former Swiss ambassador demonstrates that the modern mission materialized through hydropower and development cooperation was essential to curtail communist currents: 'job opportunities for the people of the Sierra should be created ... in areas near cities, where communist propaganda can easily penetrate. Apart from agrarian reform and mining, no major projects can be carried out for the time being, as the population is not ready for this' ${ }^{61}$ This suggests that the Electric Companies' hydraulic mission involving Swiss engineers was deeply enmeshed in political agendas and ideas of modernizing nature and people.

Local communities still internalize and reproduce the narrative depicting the Electric Companies as saviours and light bearers: 'thank God the company came' and 'thanks to the hydropower plant we had light when other communities were still in the dark'. Especially in communities that receive water from hydropower plant tunnels, Pablo Boner enjoys legendary status: 'He always came to our community and participated in our communal work days, dancing and drinking side by side with us. He was like us'. ${ }^{62}$ Similarly, it is said that he modestly insisted that it was the mountains and not him who made the Rímac hydropower marvel possible. ${ }^{63}$ This suggests that, for Boner himself, his work was strongly motivated by a fascination with the existing possibilities for hydropower and the drive for progress.

The period of intensive interventions in the Rímac watershed thus resulted in the construction of water transfers and highland dams. The hydropower company acquired a privileged position for accessing and controlling water, assigning rural communities a subordinate position. Framing hydropower development as bringing progress and modernity, providing light and dominating nature, further supported such hierarchical thinking and arrangements. Rímac watershed history also shows how urban and rural histories have become increasingly entwined during the last century. Through the construction of the hydraulic infrastructure and the resulting redirection of water flows, the material as well as political-administrative reach of the city, its interests and electricity demands redefined the rules that governed the watershed territory.

\section{Growing urban water demands and expanding supply networks for Lima, 1970s to today}

After the inauguration of the trans Andean water transfer and the Matucana hydropower plant in 1972, the Electric Companies were nationalized and renamed Elektrolima during Juan Velasco's military rule. It stayed a public company until 1994, when it was privatized during the neoliberal government of Alberto Fujimori. From 1994 to 2016 the company was known as EDEGEL.

In the late 1970s, urban water demands started to increase and, as a response, Lima's Drinking Water Company SEDAPAL began to look for additional water resources in the adjacent watersheds. As Elektrolima had an interest in maintaining electricity production levels in the existing hydropower plants, several joint water supply projects were implemented with differing financial and operational arrangements: the Yuracmayo reservoir in 1994, the Marca III project in 1999 and Marca IV in 2012. ${ }^{64}$

\footnotetext{
60 N. Hidalgo and C. Mariotti, Precursor de la responsabilidad social empresarial en el Perú, 21 December 2011, http://patrimonioindustrialperu.blogspot.pe/2011/12/ last accessed 15 November 2017.

61 Swiss Embassy to technical cooperation delegate, 22 August 1961, 1.

62 Interview with community members, Santa Eulalia watershed, 21 June 2015 and 20 March 2016.

63 Interview with A. Boner, Lima, 26 April 2016.

64 Hommes and Boelens, Urbanizing rural waters.
}

In this period, the role of the watershed changed from being a source of energy to a source of drinking water for the growing city. ${ }^{65}$ The provision of drinking water - and no longer the provision of energy - came to be seen as essential for turning Lima into a modern city. ${ }^{66}$ Another particularity of this period was that the emergence of SEDAPAL as a new powerful actor in the Rímac led to an alliance of convenience with Elektrolima. ${ }^{67}$ This alliance united financial, political and discursive powers to finance costly megaprojects, to ensure sufficient political support, to obtain legal permissions, and to promote multipurpose projects legitimized by referring to the human right to water and electricity required for development. ${ }^{68}$ In particular, the moral and legal prioritization of drinking water provision shields both actors and their joint water supply projects from potential contestations, and secures desired water flows. For the hydropower company this has been an important safeguard given the decreased dependency of Lima on electricity produced in the Rímac watershed. ${ }^{69}$ The drinking waterhydropower alliance has strengthened the presence and control of urban actors in the watershed, reinforcing established use hierarchies.

In the next section, two case studies will demonstrate the diversity of impacts that the Rímac's socio-territorial history continues to have: first, the current management of the Huarochirí Lakes and, second, the water vents from the hydropower company's tunnels, which provide irrigation water for communities. These cases show that the history of the Rímac watershed is not a blackand-white story of water deprivation but rather one of complex, entangled, multidimensional relations. It also shows how changing beliefs and diverging recognitions of the watershed's history result in continuous renegotiation of socio-territorial arrangements.

\section{Relations of dependence in the Rímac watershed today}

The Huarochirí Lakes are an important part of the Rímac watershed. In 2017, fifteen of the largest lakes were being used and managed by the main hydropower company Enel, giving them key decision-making power over water resources. Though the lakes' importance for hydropower generation has diminished in terms of quantity since the trans Andean water transfer was inaugurated, they still provide significant emergency reserves. If the transfer tunnel collapses hydropower plants and Lima would rely strongly on them. At the same time, the reservoirs and highland lakes provide essential irrigation water to communities.

As the historical analysis has shown, the lakes' ownership and management changed significantly over time. Yet, several historical events and developments have become obscured, forgotten or reinterpreted. Most strikingly, peasants in communities today say that the hydropower companies alone dammed the lakes, rather than an alliance of different downstream users. This lends legitimacy and recognition to the current situation, seeing the builder as the rightful owner and manager. This notion of 'hydraulic property

\footnotetext{
65 See, for example, SEDAPAL, SEDAPAL invoca no contaminar el río Rímac principal fuente de agua para Lima y Callao, Press Release 72, 2014, Lima.

${ }^{66}$ Many scholars have analysed how securing drinking water for urban development is regarded as decisive for achieving urban modernity, see Banister and Widdifield, The debut of 'modern' water; I. Illich, H2O and the Waters of Forgetfulness, Dallas, 1985; M. Kooy and K. Bakker, Technologies of government: constituting subjectivities, spaces, and infrastructures in colonial and contemporary Jakarta, International Journal of Urban and Regional Research 32 (2008) 375-391.

67 Interview with SEDAPAL representative, Lima, 17 August 2015.

68 SEDAPAL, La Atarjea: Revista Institucional del Servicio de Agua Potable y Alcantarillado de Lima 1 (2011); S.M. Sheen, El viaje del agua, 31 March 2016, http://www. elperuano.pe/noticia-el-viaje-del-agua-39616.aspx last accessed 10 January 2018.

69 Interview with former employee of EDEGEL, Lima, 23 March 2016.
} 
creation', whereby water rights and property relationships become inscribed in hydraulic artefacts and organize their use and control, is deeply ingrained in Andean communities. ${ }^{70}$ So, consensus about 'who' is largely clear (though inaccurate), but details about water use agreements, payments to communities or expropriations are ambiguous. As one farmer explained, the hydropower company 'asked the community for permission to build the dams, and our forefathers agreed, but we don't know if they really paid something for it - which they should have'. In this narrative, current peasants dissociate themselves from their forefathers, portraying them as uneducated and destitute: 'Our forefathers could not negotiate good agreements because they didn't have education or know their rights. The companies, by contrast, came well prepared'. ${ }^{71}$ The company currently managing the reservoirs is also not explicit about how they were acquired, and their official water use permits state the amount of water intake of each plant without specifying original water sources and use rights for the Huarochirí Lakes. ${ }^{72}$ This suggests that the legal situation of reservoir appropriation, ownership and management is blurred, while rules of practice clearly put the hydropower company in control. This is a major advantage for the company as it condones agreements that were negotiated under possibly unequal power relationships. Concessions are generally portrayed as a taken for granted historical fact.

Yet, the broad acceptance of the company's management exists side by side with narratives about local ownership of lakes and water ('our territories, our lakes, our water'), exemplified by statements such as 'they are using our water and making profit out of it'. ${ }^{73}$ Interestingly, these narratives also include a profound scepticism towards the Peruvian state, which is believed to be complicit in the appropriation of water resources: 'The companies now own the water because the state owns it, so we cannot say it is ours anymore'; 'Nowadays state authorities and companies manage and administer the water and they are going to allow only efficient uses in the future. They are going to measure each water user's productivity and decide who to give water to, leaving us without sufficient water'. ${ }^{74}$ The state and state law are thus not regarded as protective but rather as potential threats to communities' water interests, which is also due to Peru's neoliberal natural resource governance policies that facilitate the transfer of community water resources to extractive industries, increasingly excluding communities from water control. The potential weakening of community interests vis-à-vis urban interests in the Rímac watershed is further enforced as the water used for hydropower is also the drinking water for Lima, which has priority under national law and international guidelines. The consolidation of water uses is a strategic, modernist cultural-political conflation of meanings and usage rights, guaranteeing water supply for hydropower companies. ${ }^{75}$ As a former hydropower company engineer stated, when communities try to reclaim water rights 'the company can wash its hands, claiming the water is not theirs but SEDAPAL's' ${ }^{76}$ The local water authority's discourse tends to simply stress the fact that the correct

\footnotetext{
${ }^{70}$ R. Boelens and J. Vos, Legal pluralism, hydraulic property creation and sustainability: the materialized nature of water rights in user managed systems, COSUST 11 (2014) 55-62.

71 Interview with community member, Santa Eulalia watershed, 17 March 2016.

72 For a water use license, see Ministry of Agriculture, Resolución Administrativa 119-95/AG-UAD.LC/ATDR.CHRL, Lima, 1995.

73 Interview with community member, Santa Eulalia watershed, 7 August 2015.

74 Interviews with community members, Santa Eulalia watershed, 17 and 18 March 2016.

75 B. Duarte-Abadía and R. Boelens, Disputes over territorial boundaries and diverging valuation languages: the Santurban hydrosocial highlands territory in Colombia, Water International 41 (2016) 15-36; W. Espeland and M.L. Stevens, Commensuration as a social process, Annual Review of Sociology 24 (1998) 313-343.

76 Interview with former employee of EDEGEL, Lima, 23 March 2016.
}

legal procedures were followed when damming and tapping lakes. Community complaints are devalued in advance, suggesting that complaining is just a characteristic trait of peasant communities: 'The companies received authorization to build dams and use the water in their power plants. However, now most certainly communities will start saying "these are our lakes, this is our water"'. ${ }^{77}$ Thus, according to their interests and positions, actors remember or imagine differently how control of the Huarochirí Lakes was established, whether it is legitimate and how it could potentially be maintained or altered in the future. Water use and control are thus constantly renegotiated and history takes a central role in these renegotiations, both in terms of questioning current arrangements as well as sustaining them.

Though certain amounts of water can still be diverted to agriculture in most cases, property structures and management arrangements increasingly raise concerns. Communities feel dependent on the company's goodwill, limiting their autonomy to manage water resources. One example is that a mayor's request to use reservoirs for fish farming was denied; another is that an intra basin water transfer project by the Association of Huarochirí Communities has to negotiate with the hydropower company about which water resources to use. ${ }^{78}$ Concerns about this dependency were already expressed in $1941 \mathrm{by}$ the president of the upstream community of Huanza: 'we have possessed water use rights for lake [Carao] since immemorial times [and] request the Ministry of Public Works to officially provide us with exclusive rights to use this water for irrigation, informing the ministry that these are the only waters left for the people of Huanza after all other water sources have been claimed by the Electric Companies for hydropower generation'. ${ }^{79}$

Besides highland streams, lakes, reservoirs and springs, some communities use water that comes from vents in the tunnels conducting water from one HPP to the next. As with the reservoirs, the history of water vents is ambiguous and today's relationships are characterized by dependence. Communities state that water vents were constructed as in kind compensation for the negative effects of hydropower companies' construction works, while also contradictorily portraying them as charity: 'Thank God the company came and gave us the vents and water'. ${ }^{80}$ The companies and engineer Pablo Boner are remembered as saviours who brought water and light, as exemplified by a memorial plaque at one water vent with the inscription 'San Lorenzo de Huachupampa peasant community - in gratitude to the Electric Companies for the water from vents 3, 4 and 5 (27 December 1964)' (see Fig. 5).

However, the company in charge of the tunnel has different ideas about the water vents. Some representatives agree that they were established to compensate communities for constructionrelated damages; others say vents were simply needed to remove materials from the tunnel during construction. ${ }^{81}$

Until recently, historical facts did not seem particularly important as communities could use water without severely affecting energy production. Campaigns to formalize water rights, concerns about climate change and growing urban water demands are changing this. In a water shortage, it is technically possible to close the vents at any time. This happened some years ago, when acute water shortage was used as justification to close one vent and never

\footnotetext{
77 Interview with local water authority, Lima, 4 April 2016.

78 G. Ríos López, Proyecto irrigación Cochavijila - Chicoc, unpublished document, Lima, 2014.

79 P. Rojas, Relativo a comunidades indígenas de Huanza y aguas de la laguna Carao, 1 September 1941, CAR, NAR Document 513.

${ }^{80}$ Interview with community member, Santa Eulalia watershed, 20 March 2016.

81 Interview with A. Boner, 26 April 2016.
} 
open it again. ${ }^{82}$ Similarly, the mayor of a community that depends completely on water from the tunnel is campaigning to construct water reservoirs to decrease the community's dependence, saying that 'the engineers told us that maybe in twenty or thirty years they are going to ration the water flow because the water is for Lima, and Lima continues to grow, so they will need all the water. Also, the climate is changing, ${ }^{83}$

Worries about climate change and legally established water use priorities are intrinsically rooted in the unclear legal status of water use rights from the tunnel. Even the hydropower company in charge acknowledges that formalization will be very difficult: 'to formalize, the national water authority will decide according to national water law if there is enough water to give communities for irrigation. This will be difficult, because we have the water use right for non-consumptive use, whereas their use is consumptive and they do not return water to the river as we do. Furthermore, as coowners with SEDAPAL we cannot decide over water uses'. ${ }^{84}$ Thus, SEDAPAL's water demand and official law are used to disclaim responsibility for possible future contestations, assisted by the ambivalent history of the water vents. At the same time, communities' water uses are put into an unfavourable position as they do not return water to the river like hydropower companies, but consume it. Acknowledging the difficult legal situation surrounding the vents, the local water administrator suggests that 'it would be best if communities could just find other water sources' instead of insisting on formal use rights for the water from the vents. ${ }^{85}$ Again, the communities are placed in a secondary position in the ruralurban water use hierarchy.

\section{Evolving dynamics and the renegotiation of history}

Though hydropower development and socio-territorial interventions may often trigger fierce negotiations and struggles, this research indicates that, historically, the Rímac watershed has been shaped by compromise and adjustments rather than conflicts. In particular, local communities' concerns are less about water quantities than about the distribution of costs and benefits. Claims of entitlements to benefits hinge on communities' historically rooted use and control of upstream water: 'They bring everything to Lima, for drinking water and hydropower. But the water originates from here, from the community. They simply utilize it and make their business with it without paying anything. They do not care about upstream problems'; 'Everything goes to Lima, so that they have water and light, to make their development possible. But the villages stay the same: no development, no change'. ${ }^{86}$

Despite discontent, open contestation over hydropower is rare and local communities sometimes portray themselves as helpless, which can prevent them from reacting creatively. It may even lead to condemning peer communities who do react against interventions in their territories. In the words of one peasant farmer:

In the other community they took over the hydropower company's camp during construction to paralyze the work. Those people are very difficult. Not even tourists want to go there anymore. We are different. We do not take over camps. We are quiet and solve problems in different ways, like human beings. ${ }^{87}$

\footnotetext{
82 S. Bleeker, La distribución del agua y acción colectiva comunal en la subcuenca de Santa Eulalia, unpublished paper, Pontificia Universidad Católica del Perú, Lima.

83 Interview with local mayor, Santa Eulalia watershed, March 2016.

84 Interview with EDEGEL engineer, Lima, 16 March 2016.

85 Interview with local water authority, Lima, 4 April 2016.

86 Interview with community member, Santa Eulalia watershed, 16 March 2016.

87 Interview with community member, Santa Eulalia watershed, 17 March 2016.
}

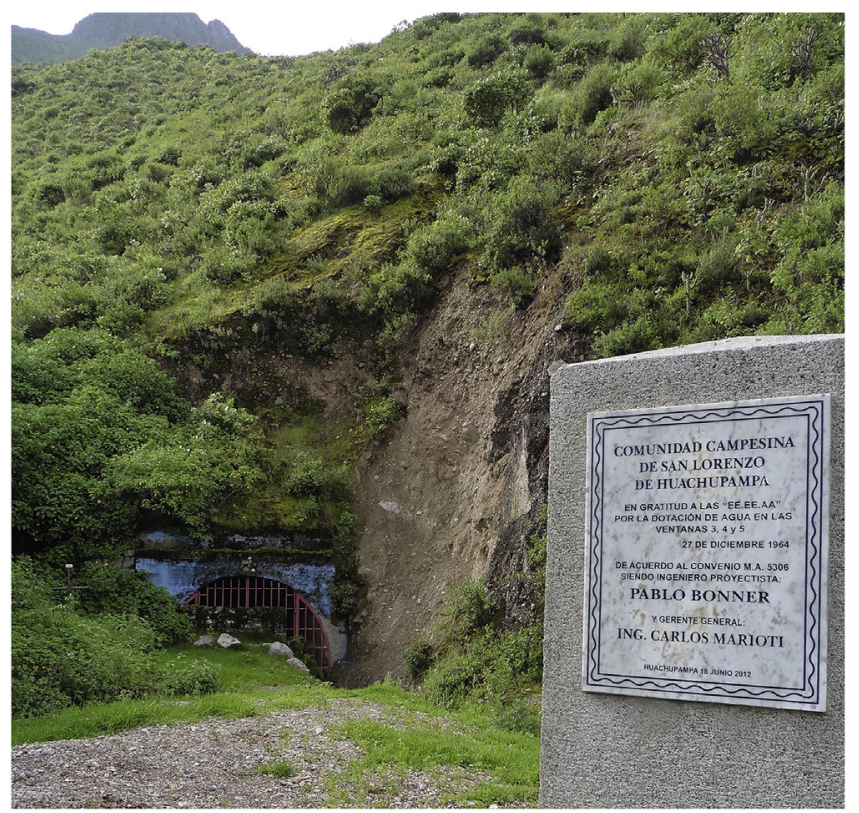

Fig. 5. Memorial plaque at water vent in San Lorenzo de Huachupampa. Photograph by Lena Hommes (2015).

Protests are thus stigmatized as undesirable and even damaging for community reputations, demonstrating how communities have internalized self-disciplining frames of 'correct behaviour'. 88 However, to say that acceptance prevails in all communities would gloss over diverse realities on the ground. The president of one community, for example, declared that 'we rent two cars and take all the farmers to Lima; in two minutes we will be on international television and tell how we don't get anything; and the people of the company will pay us .... I like to fight'. ${ }^{89}$ In some cases, community members living in Lima motivate communities to demand retroactive payment from companies for using communal territories and mobilize resources, for example accessing the National Archive for ancient land titles. Therefore, communities' proximity to Lima has manifold effects, entailing threats of losing water control but also offering diverse possibilities to contest in various ways and on various scales.

Along with growing urban water demands and changing perceptions about hydropower companies, which have come to be perceived and framed as profit seeking foreign companies that largely ignore local issues, rural communities' concerns are increasing. Hydropower companies that plan to construct new plants in the watershed now have to engage in lengthy negotiations with communities, who have become more sceptical towards any kind of intervention in their territory. These latest negotiations are not so much about rejections of hydropower but concern associated payments for land, compensation for construction damage, local employment during construction, agreements over water uses and other community support.

At the same time, concerns about future water rights and access are reinforced by climate change discourses circulating in Peru and in the Rímac watershed. Beyond general concerns about irregular precipitation patterns, peasant communities are aware that they

\footnotetext{
88 R. Boelens and M. Seemann, Forced engagements: water security and local rights formalization in Yanque, Colca Valley, Peru, Human Organization 73 (2014) 1-12; F. Cleaver, Everyday water injustice and the politics of accommodation, in: Boelens, Perreault and Vos (Eds), Water Justice, 246-259.

89 Interview with community member, Santa Eulalia watershed, 20 June 2015.
} 
share water sources with powerful players: 'Lima depends on the same reservoirs as we do and they want to control and take charge of them. That is how we will feel the impact of global warming we are worried'. ${ }^{90}$ Climate change implications for communities therefore involve growing competition for water resources, coupled with concerns about legal possibilities to claim water access and control in situations of shortage.

\section{Conclusions}

This paper has shown that the construction of hydropower plants and related hydraulic infrastructure, together with the implementation of development projects in the Rímac watershed, was profoundly driven and sustained by selected visions of modernity promoted by Lima-based national and international elites. Hydropower development came to embody what was regarded as modernity: the subjection of nature to serve a modern city. Engineers acted as key promoters of this undertaking, applying their technical skills and rationality to overcome natural obstacles and to open the road to progress and modernity for both urban and rural populations, civilizing nature and people through inherently social and political technologies. The historical analysis, coupled with a deconstruction of current water management arrangements and socio-political relations between Lima and the Rímac watershed, contributes to conceptual discussions in several ways.

First, the empirical material has shown how hydraulic technologies are shaped and sustained by their particular socio-political and legal-institutional context, entailing inscribed power relations, social norms and visions of modernity. Hydropower plants, reservoirs, water tunnels and diverted water flows have been engineered into humanised nature. Second, once installed, hydropower plants, reservoirs and underground water tunnels do not only change water flows, but also reconfigure surrounding territories in all their hydrosocial complexity. Socio-cultural, legal-institutional, economic and physical-hydrological arrangements are reconstituted. These changes need to be considered as the outcome of contested interplays among imaginaries, discourses, institutions, actor alliances, infrastructures and reconstituted ecologies. As the case of the Rímac watershed has demonstrated, it is through modern water and electricity supply projects that rural and urban actors, rules and water become enlaced in one territory. Furthermore, this paper has shown that territories are never stable. In Lima, new dynamics such as concerns about increasing competition over water resources, trigger questioning of socio-territorial arrangements and their histories. In this process, remembered history, which can differ significantly from archival history, has gained a renewed importance for claiming contemporary water use and control rights. Drinking water and hydropower companies, as well as peasant communities, mobilize different memories of hydropower development according to internalized ideas and their own particular positions within the watershed's territory.

This paper has, furthermore, shown how urbanization is symbolic, social, material, multiscalar and multidimensional, crossing conventional city boundaries and entwining the rural and the urban in a shared history, in which both are differentiated at the same time as they are connected. They are differentiated through their unequal socio-economic positioning and political hierarchization, steered by modernity and development discourses that contrast the rural as symbol of backwardness and the past with urban modernity and its utopian future. They are connected through hydraulics, normative and political institutions, and flows of water, people and ideas in both directions, from urban to rural areas and vice versa, in a relationship of increasing mutual dependence.

$\overline{90}$ Interview with community member, Santa Eulalia watershed, 17 March 2016. 